\title{
PROGRAM OF THE FIFTY-SIXTH ANNUAL MEETING OF THE AMERICAN SOCIETY FOR CLINICAL INVESTIGATION, INC., TO BE HELD IN ATLANTIC CITY, NEW JERSEY, MAY 4, 1964
}

1. Repopulating Potential of Blood and Marrow. F. E. Trobaugh, JR., and J. P. Lewis, Chicago, Ill. (introduced by T. B. Schwartz).

2. Erythrocyte Membrane Alteration Associated with Marrow Stress. R. S. Hillman and E. R. Giblett, Seattle, Wash. (introduced by C. A. Finch).

3. The Mechanism of Action of Erythropoietin. S. B. Krantz and E. Goldwasser, Chicago, Ill. (introduced by L. O. Jacobson).

4. Studies on the Mechanism of Action of Aldosterone. G. A. Porter, R. Bogoroch, and I. S. Edelman,* San Francisco, Calif.

5. An Aldosterone Biosynthetic Defect in a Salt-wasting Disorder of Infancy. S. Ulick,* K. K. Vetter, E. Gautier, G. L. Nicolis, J. R. Markello, and C. U. Lowe,* New York and Buffalo, N. Y.

6. Steroids Secreted by the Fetal Adrenal Cortex. W. R. Eberlein,* Philadelphia, Pa.

7. The Source of Energy for Active Sodium Transport in the Toad Urinary Bladder. R. P. Davis, M. Canessa-Fischer, C. M. Edelmann, Jr., and L. HoffMaN, New York, N. Y. (introduced by H. A. Eder).

8. Specificity of Sodium Transport and the Biologically Active Form of Sodium Ion. H. S. Frazier, Boston, Mass. (introduced by P. C. Zamecnik).

9. Evidence for a Common Carrier in the Renal Reabsorption of All Alkali Cations. M. WALSER * and W. J. Rahill, Baltimore, Md.

10. Isolation and Characterization of the Long-acting Thyroid Stimulator of Graves' Disease. J. C. MEEK, A. E. Jones, U. J. Lewis, and W. P. VanderLaAn, $\nmid$ La Jolla, Calif.

11. The Carnitine-dependent Distribution of Fatty Acyl CoA's into Cellular Compartments. R. BressLer and R. I. Katz, Durham, N. C. (introduced by W. Nicholson).

* ASCI, active member.

f ASCI, emeritus member.
12. The Impairment of Carbohydrate Tolerance by Elevated Plasma Free Fatty Acids. D. S. Sch ALCH and D. M. Krpnis,* St. Louis, Mo.

13. Black Liver Disease in Corriedale Sheep: A New Mutation Affecting Hepatic Excretory Function. I. M. Arias,* L. Bernstein, R. Toffler, C. Cornelius, A. B. Novikoff, and E. Essner, New York, N. Y.

14. Inhibition of Protein Synthesis: A Mechanism for the Production of Impaired Fat Absorption. S. M. Sabesin, G. D. Drummey, D. M. Budz, and K. J. Isselbacher,* Boston, Mass.

15. The Role of Serum Factors in Reticuloendothelial Blockade. M. G. Koenig, R. M. Heyssel, M. A. Melly, and D. E. Rogers,* Nashville, Tenn.

16. Glomerular Lesions Induced by Intravenous Injection of Streptococcal M Protein. F. S. Kantor, New Haven, Conn. (introduced by E. Atkins).

17. Immunoglobulins: Clarification of Their Significance in Renal Disease and Demonstration of Response to Immunosuppressive Therapy. A. F. Mich AEL, K. N. Drummond, R. A. Good,* and R. L. Vernier,* Minneapolis, Minn.

18. Human Antibody to Bence Jones Proteins. W. V. Epstein and D. Gross, San Francisco, Calif. (introduced by E. Jawetz).

19. Single Peptide Differences between $\gamma$-Globulins of Different Genetic $(\mathrm{Gm})$ Types. E. C. Franklin,* M. Meltzer, H. H. Fudenberg, ${ }^{*}$ and B. Frangione, New York, N. Y., and San Francisco, Calif.

20. Genetic Abnormalities in Hereditary Angioneurotic Edema. P. Charache, V. Donaldson, J. Pensky, P. Fireman, F. S. Rosen, and C. A. Janeway, $\nmid$ Boston, Mass., and Cleveland, Ohio.

21. Force-Velocity Relations in the Human Heart. E. H. Sonnenblick, G. Glick, A. G. Morrow, and E. Braunwald,* Bethesda, Md.

22. Pacemaker Periodicity in Atrial Fibrillation. E. J. Battersby, Nashville, Tenn. (introduced by E. V. Newman). 
23. Determination of Digitoxin in Plasma by Double Isotope Dilution Derivative Assay. D. S. Lukas and R. E. Peterson,* New York, N. Y.

24. Implication of the Kallikrein System in Production of the Carcinoid Flush. K. Melmon, W. Levenberg, J. A. Oates, L. Gillespie, Jr., and A. Sjoerdsma,* Bethesda, Md., and Nashville, Tenn.
25. The Role of Connective Tissue in Pulmonary Mechanics. G. M. Turino,* R. V. Lourenço, and G. H. MCCR.ACKen, New York, N. Y.

26. The Response of the Retinal Circulation to Hyperbaric Oxygenation. H. A. Saltzman, L. Hart, E. Duffy, and H. O. Sieker,* Durham, N. C.

\section{LISTING OF TECHNICAL EXHIBITS AT THE FIFTY-SIXTH ANNUAL MEETING OF THE AMERICAN SOCIETY FOR CLINICAL INVESTIGATION, INC., 1964}

\begin{tabular}{|c|c|}
\hline ABBotT LabORATORIES & \#25 \\
\hline AdVANCED InStruments, Inc.* & \#19 \\
\hline American Optical Co., Instrument Div. & \#32 \\
\hline Avionics Research Products Corp. & \#44 \\
\hline Becton, Dickinson and Co.* & \#15 \\
\hline Blakiston Div., McGraw-Hill Book Co.* & \#50 \\
\hline Warren E. Collins Inc. & \#42 \\
\hline CORBIN-FARNSWORTH, INC. & \#38 \\
\hline Corning Glass Works & \#51 \\
\hline Coulter Electronics Sales Co.* & \#23 \\
\hline F. A. Davis Co. & $\# 27$ \\
\hline Electrodyne Co., Inc. & \#13 \\
\hline Electronics for Medicine, Inc. & \#35 \\
\hline F \& M Scientific Corp.* & $\# 31$ \\
\hline General Diagnostics Div., Warner-Chilcott Labs.* & \#47 \\
\hline Gilford InStrument Laboratories, Inc.* & $\# 37$ \\
\hline Grune \& Stratton, Inc.* & $\# 20$ \\
\hline Hoeber Medical Div., Harper \& Row & \#33 \\
\hline Institute for SCIENTIFIC In FORMation & \#16 \\
\hline INSTRUMENTATION AsSOCIATES, INC.* & \#3 \& 4 \\
\hline INTRUMENTATION LABORATORY INC.* & \#7A \\
\hline Intercontinental Medical Book Corp. & \#56 \\
\hline International Chemical \& Nuclear Corp. & \#12 \\
\hline LEA \& FEBIGER & \#10 \\
\hline E. Leitz, InC.* & $\# 26$ \\
\hline LEXINGTON INSTRUMENTS CORP. & $\begin{array}{l}\# 11 \\
\# 22\end{array}$ \\
\hline
\end{tabular}

\begin{tabular}{|c|c|}
\hline Little, Brown \& Co. & \#18 \\
\hline The London Co.* & \#5 \\
\hline The Macmillan Co.* & \#24 \\
\hline Metrix, InC. & \#54 \\
\hline Millipore Filter Corp. & $\# 41$ \\
\hline The C. V. Mosby Co. & \#43 \\
\hline New England Nuclear Corp. & \#55 \\
\hline Nuclear-Chicago Corp.* & \#6 \\
\hline Nuclear Consultants Corp. & $\# 14$ \\
\hline Oxford University Press & \#53 \\
\hline Packard Instrument Co., Inc.* & $\# 1 \& 2$ \\
\hline Pentex, Inc.* & $\# 30$ \\
\hline Picker Nuclear, Div. Picker X-Ray Co & \#28\& 29 \\
\hline PhIPPS \& BiRd, INC.* & $\# 48$ \\
\hline Precision Systems & \#7 \\
\hline W. B. Saunders Co. & \#39 \& 40 \\
\hline Scientific Industries, Inc. & \#34 \\
\hline SONOMEDIC CORP.* & \#52 \\
\hline E. R. SQuib \& Sons * & $\# 21$ \\
\hline VANGUARD INSTRUMENT CORP. & $\# 17$ \\
\hline Volk Radiochemical Co. & $\# 45$ \\
\hline The Waters Co.* & \#9 \\
\hline Wilkens Instrument \& Research, Inc. & \#49 \\
\hline The Williams \& Wilkins Co. & \#46 \\
\hline $\begin{array}{l}\text { Year Book Medical Publishers, Inc.* } \\
\text { The Coca-Cola Co.* }\end{array}$ & \#8 \\
\hline
\end{tabular}

* See advertisement in this issue. 